\title{
SYNERGY OF LANGUAGE LEARNING AND VIRTUAL LEARNING PLATFORMS IN STUDIES
}

\author{
Rūta Buivydienè \\ Jelena Mamčenko \\ Inga Piscikiene \\ Brigita Šustickienè \\ Vilnius College of Technologies and Design, Lithuania
}

\begin{abstract}
The paper presents comprehensive study of applicability of various language learning platforms to the development of foreign language that are indicated in the Common European Framework of Reference for Language (CEFR). To carry out the research, a number of language learning platforms that are used as an alternative to Learning Management Systems (such as Moodle) was selected and on their basis a questionnaire was designed. The quantitative research involved faculty students and lecturers of Vilnius College of Technologies and design. The results of the research permitted us to draw a list of recommendations on which language learning platforms are best to be used in EFL classrooms to facilitate the development of foreign language competences.
\end{abstract}

Keywords: apps, social media, e-learning, blended learning, Learning Management Systems.

\section{Introduction}

Foreign language abilities not only widen cultural and social abilities, but they are among the main factors permitting an active participation in the knowledge society. They ensure a successful integration of Lithuania into European and the global society. One of the ways for Lithuanian institutions of higher education to consolidate their position in the international scientific research and higher education area is to find an appropriate learning instrument that would facilitate language study process for both students and lecturers. Ability to communicate in a non-native tongue is important not only to the prospective employers, it also provides students with a better possibility to participate in international exchange programmes (e.g. Erasmus), to study abroad, and to be a fully-fledged participant in study process (able to read literature in a foreign language, participate in multicultural discussions, etc.). It is important to ensure that Lithuanian graduates develop competitive edge for their future participation in Lithuanian and in global labour markets. 
A good knowledge of two or three foreign languages is gradually becoming a compulsory part of higher education (a decision of LR Seimas 'Regarding regulations for national educational strategy in 2013-2022). High quality of language teaching and learning, and especially of ESP, is of vital importance for internalization of higher education institutions and for increasing employment possibilities of the graduates.

The concept of foreign language teaching in higher schools has been developed on the grounds of various documents regarding multilingualism and issued by Lithuanian Government, European Commission and Council.

The rapid development of information technologies resulted in their becoming an indispensible part of our daily routine; it comes as no surprise that such potential of technological innovations did not go unnoticed by foreign language instructors (Garrett, 2009).

Rapid development of technologies resulted in the drop of the prices of mobile devices (Geddes, 2004). Affordability of such gadgets as mobile phones, laptops, tablets, smart phones shaped environment conductive to the development of new learning methodology.

Affordable mobile technologies and their use in social networking is the reality of the 21st century. The last two decades saw the most successful and instantaneous integration of technology into everyday lives of common users (Katz, 2008).

Distance learning environment is no longer the only media that fosters foreign language learning. Since the emergence of mobile learning environment developing language skills has become a matter of individual mindset rather than the necessity to be taught (Lin \& Hsieh, 2001).

Respondents acknowledge the additional value of such programmes in the language learning process. There is a widespread opinion that they present a prospective and beneficial language learning methodology with elements of gamification. On the other hand, experience of many users imply that the method is only valuable as supplementary to the traditional classroom foreign language learning activities. The reason for applications serving only supplemental function is predetermined by two limitations: lack of motivation to coordinate one's individual learning process and absence of formal assessment.

\section{Review of Information Technologies Used in Foreign Language Learning}

As information technologies are increasingly gaining centrality in everyday life, most of societal activities are inevitably affected. Educational institutions also do not hesitate to exploit technologies to achieve better quality of studies and 
to meet the needs of contemporary community of learners. ICT developments to support teaching and learning form a core part of institutional strategy and policy (Conole, 2004). It is a common practice for a college or university to actively use virtual learning platforms. The latest research suggest that Moodle is the dominant course management system (Trends in eLearning, 2010) in higher education as it is distinguished by its convenience, quality, variety of functional elements that facilitate study process. Moodle is used by almost all institutions of higher education in Lithuania, among which is Vilnius College of Technologies and Design.

However, current trends in eLearning indicate that a single eLearning system, such as Moodle, will not meet every institution's demands (Britian \& Liber, 2004), and eLearning solutions will continue to diversify in response to personalized needs. Institutions are faced with prioritizing solutions, with many focusing predominantly on mobile apps followed by web-based apps (Tamarkin \& Rodrigo, 2011).

From the very beginning, the application of mobile technologies to foreign language learning has above all targeted English, with over $60 \%$ of all implementations focusing on ESL/EFL (Burston, 2015).

Indeed, foreign language instruction is contributed by entire plethora of technological means to facilitate the learning process. One of the main characteristics of mobile devices is portability, which enables learners to move mobile devices and bring learning materials (Huang \& Sun, 2010).

Mobile learning technology is more useful for doing activities outside the classroom. Such activities enable learning to be more directly connected with the real world experiments. Moreover, learning through mobile phones outside the classroom has the advantage of better exploiting the learner's free time; even the students on the move can improve their learning skills (Kukulska-Hulme, 2009).

Internet websites, differently from mobile apps, offer learners a lot of flexibility in terms of the material scope, since they provide information on how to find additional material on the studied topics, learners are usually presented with authentic material to support the learning process, they also provide students with ideas of what to expect and to require from classroom activities.

\section{Research Method}

The purpose of this research was twofold. First aim was to find out students ${ }^{6}$ opinion about the benefits of incorporating mobile apps and internet sites into the Moodle environment in seeking to increase the quality of foreign language learning, and the second was to compare the suitability of these two language learning means to be used as part of the traditional classroom course. To achieve this end, students were asked to provide the names of apps and of websites that 
they have used for educational purposes. Later, the list of five most frequently used apps and three websites were given to the target group. Students were asked to use the IT tools for two weeks. Eventually, researchers designed a survey and later analysed the obtained results.

Thus, this study employed a descriptive quantitative approach to elicit the perceptions of the learners about their experiences while using various language learning apps and internet sites for EFL. A quantitative data from the students was collected in 2016; it was obtained by the use of 234 questionnaires, filled in by full time students of Vilnius College of Technologies and Design (41\% first year students, $35 \%$ second year students, $24 \%$ third year students). $81 \%$ of respondents learn English as their first foreign language, $5 \%$ study German and $14 \%$ - Russian.

For many years VTDK has fostered a traditional „brick and mortar” classroom teaching. However, the growing importance and role of digital media in learners' everyday lives, the need to be mobile even when studying has resulted in shifting to blended learning and incorporation of information technologies into the study process. This change has answered the needs of contemporary, technology savvy learner who no longer wants to stick to the classroom and does not link study process with course books.

Questionnaires were composed of 17 questions of both open and closed format. It ensured better grounded and more credible information.

\section{Results of the Survey}

The first survey question addressed the experience of improving foreign language skills. $87 \%$ of respondents stated to have had experience in enhancing foreign language skills. $4 \%$ of them said they had been improving grammar skills, $23 \%$ had been working on listening, $47 \%$ expanded their vocabulary, $26 \%$ developed their spoken skills. Regarding the level of the foreign language skills, $83 \%$ of respondents claimed their abilities were intermediate, $6 \%$ reported to have upper-intermediate language skills, and $11 \%$ - pre-intermediate. Since the foreign language of vast majority of respondents ( $82 \%)$ appeared to be English, it was decided to address only those who studied this particular language. Majority of the survey's participants (88 \%) have been studying English for 11-15 years, 8 $\%$ have learned the language for $6-10$ years, $3 \%-3-5$ years, and $1 \%$ admitted to have learned it for more than 15 years.

Respondents were also asked to describe their foreign language proficiency regarding the four competences named in the Common European Framework of Reference for Language (CEFR), i.e. reading, writing, spoken production and spoken interaction. The results are presented in Figure1. 


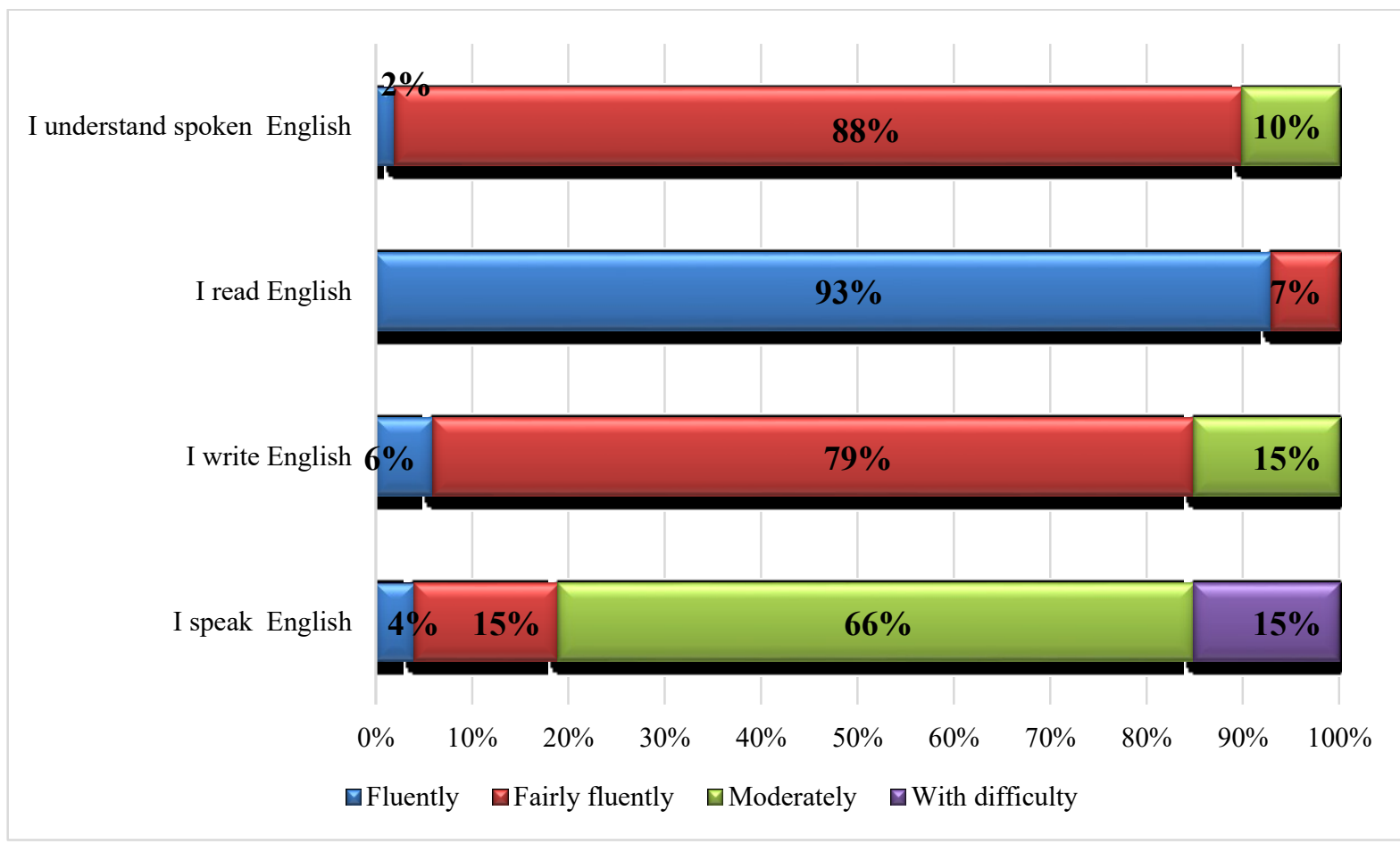

Figure 1 Foreign language proficiency

$27 \%$ of respondents explained they improved foreign language skills because they needed to communicate in English, $23 \%$ wanted to retain the level of the skills they had already had, $14 \%$ said they required English in professional activities, $12 \%$ used it for studies, $17 \%$ developed skills for leisure and travelling, $4 \%$ of respondents claimed they used English to search needed information, while $3 \%$ claimed they did not have any particular reason for studying the language and that they did not know where they would use the newly acquired knowledge.

When explaining their attitude to the use of technologies in foreign language learning, $76 \%$ respondents claimed that development of reading, writing, spoken production and spoken interaction competences could be fostered by the extensive use of technology (e.g., class lecture notes online, computer simulations, PowerPoint presentations, streaming video or audio, etc.). $8 \%$ expressed preference taking courses that use a moderate level of technology (e.g., e-mail, several PowerPoint presentations, some online activities or content). $5 \%$ preferred taking courses that use limited technology features (e.g., e-mail to instructors and limited use of PowerPoint in class)., $5 \%$ said they favored courses that use no information technology, and $6 \%$ of respondents were strong believers in technology, they wished to attend courses that use technology exclusively (i.e., are entirely online with no required face-to-face interactions).

To develop reading, writing, speaking skills $72 \%$ of respondents stated to have used mobile applications, $93 \%$ reported having used internet websites. The 
majority of the participants in the survey named such language applications as Duolingo, Busuu, Memrise, 6minuteenglish. The most popular websites among respondents were Englishlink.com, Anglu24.lt, esl-lab.com.

The 2nd figure presents the impact of information technologies on the development of language competences. As the figure depicts, vast majority of respondents feel they were able to improve their vocabulary and listening comprehension skills. Ability to speak was least affected by information technologies.

As it was discussed above, the technological age we live in has presented the global community with high numbers of language learning internet websites and mobile apps. Although these are usually easily accessible, the existing variety and wide choice tend to confuse users (Huffman \& Barbara, 1998). Figure3 presents opinion of the respondents regarding the exploitation of two most frequently used technological devices in the process of language learning. As the Figure indicates, the three most popular uses of computers were reported watching authentic videos, looking up synonyms, and revising and practising grammar. Vocabulary and pronunciation, social networking and listening to music tended to be addressed by the use of mobile phones.

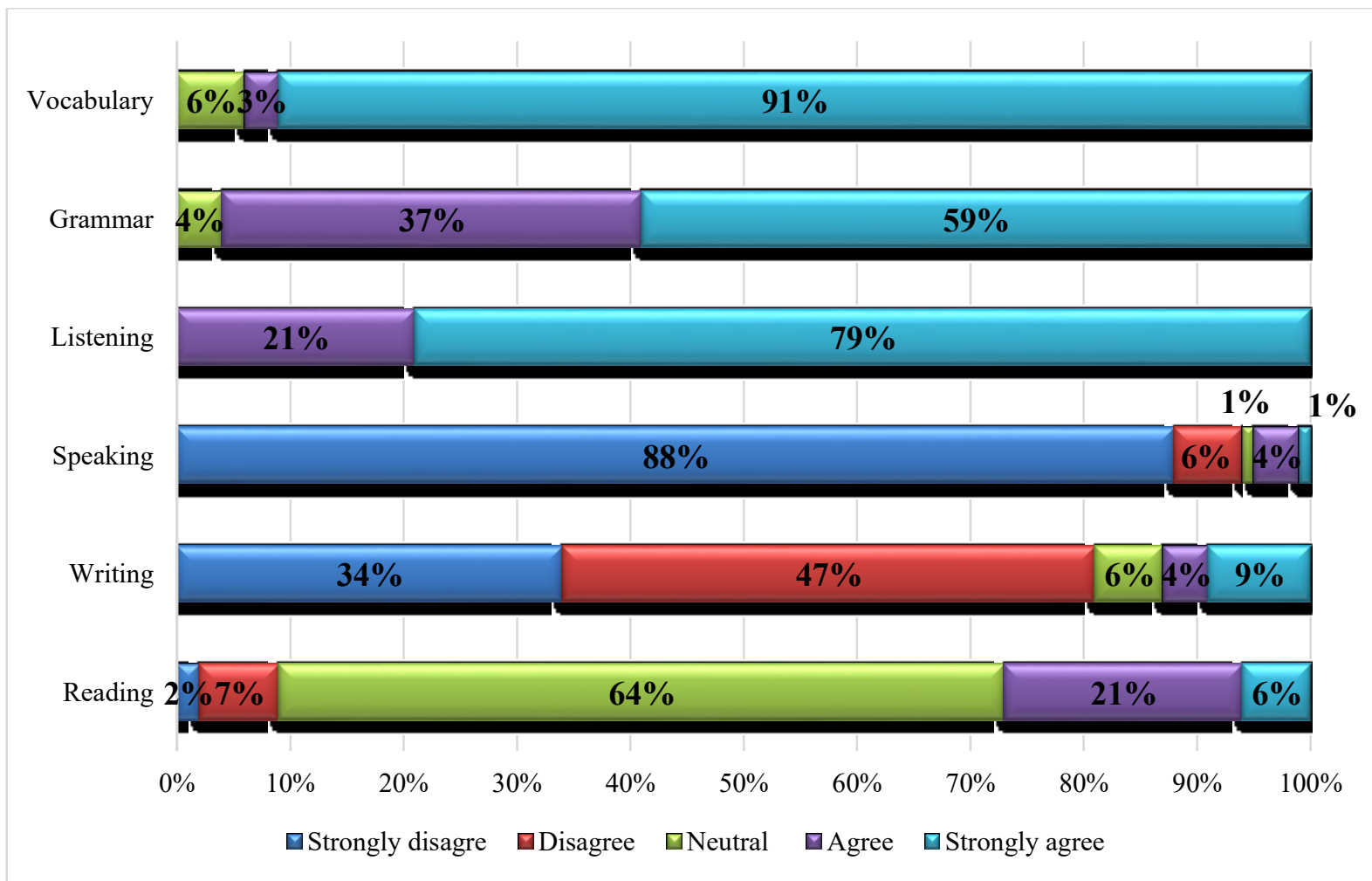

Figure 2 Impact of information technologies on the development of different language competences 
When considering the benefits of the mobile apps use in the field of foreign language learning, $91 \%$ of the target group said that the mobile applications were especially useful for drilling and enhancing vocabulary, memorizing grammar forms, and $9 \%$ of respondents found apps suitable for improving writing skills, pronunciation and grammatical accuracy.

$88 \%$ of the participants in the survey found EFL websites helpful in developing the correct sentence structure, in improving reading comprehension, developing topic-related vocabulary; respondents also said that the websites provide resources for extra practice at any time and at individual pace.

Respondents were asked to consider the benefits of each mobile application with regards to the four competences indicated in Common European Framework of Reference for Language. The results are presented in Table 1.

Table 1 The table captions should be placed above the table

\begin{tabular}{|l|c|c|c|c|}
\hline & Reading & Listening & $\begin{array}{c}\text { Spoken } \\
\text { production }\end{array}$ & $\begin{array}{c}\text { Spoken } \\
\text { interaction }\end{array}$ \\
\hline Hello Talk (MA) & 17 & 53 & 41 & 49 \\
\hline Busuu (MA) & 22 & 34 & 23 & 7 \\
\hline Memrise (MA) & 14 & 63 & 17 & 18 \\
\hline $\begin{array}{l}\text { Learn English grammar } \\
\text { (MA) }\end{array}$ & 8 & - & - & - \\
\hline 6 minute english (MA) & 115 & 10 & 25 & 13 \\
\hline Breaking news english (W) & 111 & 158 & 98 & 201 \\
\hline Simple English news (W) & 184 & 147 & 79 & 96 \\
\hline About.com (W) & 89 & 55 & 48 & 44 \\
\hline
\end{tabular}

MA - mobile appication;

$\mathrm{W}$ - website

A vast majority of respondents (86\%) considered EFL websites suitable for supplementing traditional English language course and supported the idea of including them into the Moodle system. Only $7 \%$ of the participants suggested the same about mobile apps. Almost third of the respondents (63\%) thought them suitable for individual studies of a foreign language.

More than two thirds of the survey participants used language learning websites at the college ( $71 \%$ ) and at home (68\%). Mobile apps tended to be used in public places - parks, shops, public transport, whereas only slightly less than a quarter of respondents used them at home or college.

\section{Conclusions and Recommendations}

The findings of the survey suggest the importance of integration information technologies into the EFL classroom material. Language learning instructors 
should consider incorporating EFL website's material into their classroom agenda, and could suggest students using mobile applications for revising and expanding English vocabulary, for drilling grammatical forms, since the apps offer flexibility in terms of time and place, provide students with a possibility take a more active approach to their learning, make learning more personalised. Technology supports student achievement. When integrated into instruction appropriately, technology has significant positive effects on student achievement in reading, literacy, mathematics, and science (International Society for Technology in Education, 2008).

Social networking is another media that is increasingly being used in the field of education. Foreign language learning could also benefit from such trend if social media is incorporated into the virtual learning environments in addition to other material. The latest technology intensifies social interaction necessary for learning process, encourages the community of learners to join social groups, contributes to the achievement of learning goals. However, it is noted that none of the IT tools can realize the distance learning methods and the most effective way to achieve learning goals is to combine various technologies.

Modernization tasks for education and teaching cannot be carried out without implementation of information technologies into all their fields. The use of IT supports the development of new teaching forms and encourages their integration into traditional teaching and learning methods, this way upgrading the quality of the studies.

\section{References}

Britian, S., \& Liber, O. (2004). A Framework for the Pedagogical Evaluation of eLearning Environments. Downloaded from http://www.elearning.ac.uk/resources/ VLEFullReport08.doc

Burston, J. (2015). 20 years of MALL project implementation: A meta-analysis of learning outcomes. ReCALL $27 \quad$ (1), 4-20. Downloaded from http://journals.cambridge.org/action/displayAbstract?fromPage $=$ online $\&$ aid $=9455682 \&$ fileId $=$ S0958344014000159

Conole, G. (2004). Cultural Change - From Learners to Managers. Keynote paper for FERL online VLE conference 2004.

Garrett, N. (2009). Technology in the service of language learning: trends and issues, republication from The Modern Language Journal, 75, 1991, 74-101. The Modern Language Journal, 93 (s1), 697-718.

Dias, S. B., Diniz, J. A., \& Hadjileontiadis, L. J. (2014). Towards an Intelligent Learning Management System Under Blended Learning: Trends, Profiles and Modeling Perspectives. Springer International Publishing.

Geddes, S. J. (2004). Mobile learning in the 21st century: benefit to learners. Knowledge Tree e-journal, vol. 30, no. 3, pp. 214-228.

Huang, C., \& Sun, P. (2010). Using mobile technologies to support mobile multimedia English listening exercises in daily life. In: The International Conference on Computer and 
Proceedings of the International Scientific Conference. Volume II, May $26^{\text {th }}-27^{\text {th }}$, 2017. 388-396

Network Technologies in Education (CNTE 2010). Downloaded from http://cnte2010.cs.nhcue.edu.tw/

International Society for Technology in Education, (2008). Downloaded from https://computerexplorers.com/Student-Achievement-Brief.pdf

Katz, J. E. (2008). Handbook Of Mobile Communication Studies. Cambridge, Mass.: MIT Press.

Kats, Y. (2013). Learning Management Systems and Instructional Design: Best Practices in Online Education. IGI Global.

Kukulska-Hulme, A. (2009). Will mobile learning change language learning? ReCALL 21 (2), pp. 157-165.

Lin, B., \& Hsieh, C. (2001). Web-based teaching and learner-control: A research review. Computers \& Education, 37, 377-386.

Tamarkin, M., \& Rodrigo, S. (2011). Evolving Technologies: A View to Tomorrow. Downloaded from http:/www.educause.edu/EDUCAUSE+Review/ EDUCAUSEReviewMagazineVolume46/EvolvingTechnologiesAViewtoTom/238392

Trends in eLearning: Tracking the impact of eLearning at community colleges. (2010). Downloaded from http://www.itcnetwork.org/images/stories/itcannualsurveymay 2011 final.pdf

Valstybine Švietimo 2013-2022 metu strategija. Downloaded from https://www.smm.lt/uploads/documents/VSS_2013-2022_2013-08-23.pdf

Jodienè, R., \& Stunžėnienè, D. (2016). Studentų užsienio kalbos mokymosi patirties analizè kaip sąlyga sėkmingam nuolatiniam mokymuisi. Studies in Modern Society . Vol. 7 Issue $1, \mathrm{p} 319-325$. 